\title{
Justice for Women-Empowerment
}

\section{Naik DN ${ }^{*}$}

Nesco Utility, Balasore, Odisha, India

*Corresponding author: Dhirendra Narayan Naik, Nesco Utility, Balasore, Odisha, India, Tel: +919438906072; E-mail: dnnaik1974@gmail.com

Rec date: April 29, 2017, Acc date: June 05, 2017, Pub date: August 31, 2017

Copyright: (c) 2017 Naik DN. This is an open-access article distributed under the terms of the Creative Commons Attribution License, which permits unrestricted use, distribution, and reproduction in any medium, provided the original author and source are credited.

\begin{abstract}
In our society women enjoy a unique position and their contribution to the Social development and progress can never be denied. In almost all parts of the world their role in building the national character is significant. Their contribution to the society is manifold and they have got multifaceted personality as they play the role of mother, sister, wife and daughter during various stages of their life. In their role in various capacities they become a part of the society. In the modern age in this new millennium they have shown their excellence in almost all fields and their contribution in political, civil \& overall growth of a country is widely appreciated and recognized and they have proved be more week and are equal with men. Despite all these, even today, a major chunk of women folk are deprives of the basic necessities of life and are being considered as a neglected segment of the society. They have become victim of the social set-up and sex-based discrimination continued to dominate the society ther by depriving them from all sort of facilities.
\end{abstract}

Keywords: Women empowerment; Economic; political; Social; Justice for women

\section{Introduction}

In our society women enjoy a unique position and their contribution to the Social development and progress can never be denied. In almost all parts of the world their role in building the national character is significant. Their contribution to the society is manifold and they have got multifaceted personality as they play the role of mother, sister, wife and daughter during various stages of their life. In their role in various capacities they become a part of the society. In the modern age in this new millennium they have shown their excellence in almost all fields and their contribution in political, civil \& overall growth of a country is widely appreciated and recognized and they have proved be more week and are equal with men. Despite all these, even today, a major chunk of women folk are deprives of the basic necessities of life and are being considered as a neglected segment of the society. They have become victim of the social set-up and sex-based discrimination continued to dominate the society ther by depriving them from all sort of facilities. They are treated unfavorably and the concept of equality and equal status has become myth for them. The modern and independent India realizing the inequality and discrimination against women has incorporates in the constitution, the Law of the land, several provisions which unequivocally declare that women should be treated at par with men at all walks of life and their should be no discrimination and specific provisions are laid down for their up-liftment. The Legislature has also not lagged behind and has come from time to time with various welfare legislations specifically directed towards the women and their protection keeping in mind the various needs and facilities they require. Judiciary is also placing the women at high places and coming out with landmark decision to protect the interest of women thereby adopting a soft approach towards the various problems they face in the society.

\section{Status of women in India}

It has been said "Yatra Narayanatu Poojyante Ramante Yatra Devatah". It means where women are respected, diving grace adores that place. Women are symbol of sacrifice, kindness, excuse, softness and tolerance. Maharshi Manu also placed women in high esteem glorifying their dignity. As he said,"upadyayana dashacharya, acharyanam shatapita sahasra pitrunam mata swabhavata pitirichete." It means that "The glory of an Acharya is more than that of ten upadhyayas, the glory of a father is more than that of hundred acharyas and the glory of a mother is more than that of thousand fathers". But a question is being raised here whether they have been able to get such place of respect in the society? The answer is a big no. Because the studies on the status of women made so far reveals that there was no practical equality between man and woman in any society. In theory they might be enjoying a respectable status but in practice they were subject to all sorts of ill treatment and misbehavior.

\section{Women during Pre-Independence Period}

The pre Independence period was dominated by the Britishers who ruled India for nearly 200 years that is from middle of 18 th century till 1947, the year India got the independence. There was around development during the British period. They gave more stress on the economic aspect with little interest on the Laws governing Hindus and Muslims. But the impact of their duel could be felt in almost all fields; economic, political, social as well as legal remarkable changes were also noticed in the lifestyle of the people. During this period the status of women changed to a great extent and remarkable development could be noticed in the lifestyle of the people. During this period the status of women changed to a great extent and remarkable development could be noticed which affected both economic and social structure of the society. Almost all the evil social customs were abolished thereby improving the quality of life of women. They were treated equal with men and substantial progress in the field of education, employment, social rights etc., was achieved. Women were given a place of pride in both social and economic structures of the society almost all the evil 
social customs were abolished thereby improving the quality of life of women. They were treated equal with men and substantial progress in the field of education, employment, social rights etc.,, was achieved. Women were given a place of pride in both social and economic structure of the society. They also enjoyed certain political rights. Thus substantial development of women took place during the British rule.

\section{Women during the Post-Independence Period}

During the early part of the twentieth century the women were not enjoying a good status a status they were supposed to have. They continued to remain under depression and maintain a low status. The reasons may be illiteracy, economic dependence, dominant nature of males, religious attitude and cast restriction. But after the end of the British rule in the year 1947 and particularly after 1950, the year, the Indian constitution came in to force, a sea change has been made when we the people adopted and enacted to give to ourselves a constitution $[1]$.

\section{The Concept of Empowerment}

The concept of empowerment flows from that of power. In the ordinary sense "Power is the capability to do anything". In the social context power can be considered "as the authority, right to command, right to govern or rule, capability to influence etc." empowerment simply means the vesting of power where it does not exist, or exist inadequately. It is a concept that does not merely concern personal identity but brings out a broader analysis of human rights and social justice. Empowerment has three elements:-

- Access to productive asset such as land, credit and technologies that can produce Income.

- Access to basic needs such as education, health services, water, fuel, shelter etc.

- Participation in decision-making [2].

\section{International Convention on Empowerment of Women}

Today as we stand at the threshold of the 21st century, we are still unable to boast of a society where there is total gender equality or gender equity. Until recently, the question of gender equality or gender equity was merely a topic of theoretical discussion. Things are changing but rather slowly. Movement from the first U.N. world conference on women. Having in view classification and object of legislation "Women" can be treated as a separate group and Special Laws can be made in their favour. . Not only this but the constitution has gone further and empowered the state to a positive act where it is needed, by giving "preferential treatment" in behalf of women.

Clause (2) of Article 16 lays down specific grounds on which citizens are not to be discriminated against each other in matters of opportunity and offices under the state. These are religion, race, caste, sex, descent, place of birth, residence or any of them. Discrimination of the basis of sex has been specifically prohibited under the constitution so as to bring women at par with men. Sex shall not be the sole ground of ineligibility for any post.

\section{Critical Approach}

The rights, which are available to women in chapter III of the constitution that is Art. 14, Art.15(1), Art.15(3), Art.16, Art.21 and Art.23 can be ensured against states and not against another individual person, because fundamental rights are available against 'state' only. For example in University of Madras v. Santa Bai [3] the respondent was refused admission to the college on the ground of 'sex' only. The syndicate of university had directed to the college under its jurisdiction not to admit women students without obtaining permission of the syndicate. Had the respondent not been a woman, she would have been admitted in the college on the basis of her marks. The Madras High Court held that the Madras University was not a 'state' and therefore, the respondent could not complain of discrimination under Art.15 (1) as Art.15 (1) of the constitution prohibits discrimination made by the 'state' only. The court rather held that university was right in refusing admission to the respondent in the colleges open for men only, because in these colleges there were no facilities for women like separate common room, toilet and the like. The decision appears to be wrong on the following grounds: Firstly, that the rule made by the syndicate does not satisfy the legal criteria for discrimination. If discrimination in fact results, it is unconstitutional, now ever sound the motive or object may be. Secondly, for want of adequate facilities, the fundamental right conferred on women cannot be denied because states itself is responsible for this creating facilities for male students and in failing to create equal facilities for women. Thirdly, omission of the word 'sex' in Art.29 (2) does not empower the state to segregate women from men in educational institution, when Art.15(1) of the constitution gives them equal right in educational institutions. Another specific example is clause (1) of Art.16 that through the constitutional provisions parliament enacted so many laws to empower the women, but the question is that how many law are properly implemented: how many women aware about their rights; even the existence provision is there in the law but still so many women are subject to cruelty, exploitation, operation and victim of make dominated society. After having the provision in Art.15 (3) and Art.16 (2) women are waiting for $33 \%$ reservation in legislation and other employment. In immoral traffic of women and girl act managing and conducing 'brothel' is an offence even though in big cities like Mumbai thousands of 'brothel' conducting and lack of minor girls and women forced and exploited for prostitution (4). Even after enactment of medical termination of pregnancy act and pre-natal diagnostic Technology (Prevention) Act, numbers of illegal adoption are doing even without the consent of concern women and kill the fetus in mother womb that is a serious crime. Every day in every city the cases of rapes are happened eve testing is going on and the cases of dowry death and cruelties are pending before judiciary for getting justice. Numbers of cases for maintenance filed by divorce or wife who is neglecting by her husband are pending before the court (5). They may or may not get the justice even after three to four years after filing the case. Suppression of Muslim women right is yet another problem. She got half status than man in the laws she is not entitle for maintenance, husband allow to do till four marriages, and talak system still there in which husband just give divorce without filing the divorce application in the court. Very recently, the legislation enacted Domestic Violence Prevention Act 2005 through which the protection is given not only the wife, but to sister, mothers, and daughter also. But the question is that now many women aware about this Act?

\section{Conclusion and Suggestion}

Today as we stand at the threshold of the 21 st century, we are still unable to boast of a society where there is total gender equality or gender equity. Until recently, the question of gender equality or gender equity is merely a topic of theoretical discussion. Things are changing but rather slowly. For women empowerment I would like to suggest 
that education is the best weapon for fighting against injustice. Illiteracy is the root of all exploitation, violence and oppression our government make laws for women, try to implement it but also take the care that each and every women in our society should be educated. Legal awareness to women rights is also necessary and most important thing that women should take care of their rights. In the word of Prof. Harold Laski-" Internal vigilance is the price of liberty and not a particular doctrine or rule of law”.

\section{References}

1. Sukanta Nanda, Law relating to women and children.
2. Sonia KD (2004) Women Empowerment and Law - Conceptual Over view. Cu.L.R.

3. Anand AS (2002) Justice for Women - Concerns and Expressions Universal Law of Publishing Company, pp: 1-271.

4. Majumdar PK (2008) The Constitution of India. Delhi Law House.

5. Ramaiah GV (1996) Right to Conceive vis-à-vis Right to Birth. AIR Jour. 136 at 140. 